\title{
Behaviour of critical elements, Au and PGE in the Ni-Co lateritic profile, Goongarrie, Western Australia
}

\author{
WALID SALAMA, MICHAEL VERRALL, HETA \\ LAMPINEN, LOUISE SCHONEVELD AND TANIA \\ IBRAHIMI
}

\section{CSIRO Mineral Resources}

Presenting Author: walid.salama@csiro.au

The Goongarrie Ni-Co project is $70 \mathrm{~km}$ northwest of Kalgoorlie, Western Australia. It contains a global resource of $\mathrm{Ni}-\mathrm{Co}$ laterite $(60 \mathrm{Mt}$ at $1 \% \mathrm{Ni}$ and $0.07 \% \mathrm{Co})$. The Goongarrie deposit extends over a strike length of $7.5 \mathrm{~km}$ and averages approximately $800 \mathrm{~m}$ wide and $40 \mathrm{~m}$ thick. The Ni-Co laterite deposit is formed by weathering of serpentinized dunite belonging to the komatiitic Walter Williams Formation. There is no known magmatic sulfide mineralisation associated with this unit, which has a strike length of over $100 \mathrm{~km}$. The Ni-Co laterite profile is $40-150 \mathrm{~m}$ thick along the Pamela Jean and Elsie North shear zones. The laterite profile is dominated by goethite, hematite and halite with stratigraphic horizons have quartz, gibbsite, chromite, magnetite and lithiophorite. Serpentine minerals, chlorite, magnesite, dolomite and talc dominate the lower part of the profile. The Ni-Co laterite profile is overlain by lacustrine clay and calcareous soil that consists of quartz, feldspars, calcite, alunite and kaolinite.

Laser ablation ICP-MS mapping showed that $\mathrm{Cr}, \mathrm{Ti}, \mathrm{V}, \mathrm{Sc}, \mathrm{Sb}$ and $\mathrm{Y}$ are associated with $\mathrm{Fe}$ oxides, whereas Ni, Co, $\mathrm{Li}, \mathrm{Mo}, \mathrm{W}$, $\mathrm{Zn}, \mathrm{Ce}$ and $\mathrm{Pb}$ are associated with $\mathrm{Mn}$ oxides. Silver and $\mathrm{Cl}$ occur together as fracture filling $\mathrm{AgCl}$. Gold is concentrated at the base of the Ni-Co laterite profile as pure, cavity-filling microcrystalline aggregates. Chromite occurs in two types: the first is zoned with variations in $\mathrm{Cr}, \mathrm{Fe}, \mathrm{Al}, \mathrm{Mg}, \mathrm{Ti}, \mathrm{Mn}$ and $\mathrm{V}$, and the second is intensely sheared with cataclastic texture and a matrix of talc and chlorite. The first hosts inclusions of $\mathrm{Ni}$ sulphides and arsenides, whereas the second hosts $\mathrm{Ni}, \mathrm{Co}, \mathrm{Cu}$, $\mathrm{As}, \mathrm{Sb}, \mathrm{Ru}$ and $\mathrm{Os}$ sulphides, $\mathrm{Pt}$ arsenides and $\mathrm{Pd}-\mathrm{Bi}-\mathrm{Sb}$ tellurides. Selenides of $\mathrm{Au}, \mathrm{Ag}$ and $\mathrm{Hg}$ are associated with millerite and exist as cavity fillings in silicates and carbonate. Laser ablation ICP-MS mapping showed that millerite contains $\mathrm{Cu}, \mathrm{Co}, \mathrm{As}, \mathrm{Bi}, \mathrm{Te}, \mathrm{Sb}, \mathrm{Ag}, \mathrm{Fe}, \mathrm{Pb}, \mathrm{Pd}, \mathrm{Ru}, \mathrm{Os}$ and $\mathrm{Au}$.

Bismuth, Te and PGE are immobile in the Ni-Co laterite and are the potential pathfinder elements for $\mathrm{Ni}$ exploration. Chromite is the best indicator mineral for Ni sulphide fertility in Goongarrie. 